\title{
16
}

\section{EARLY CHILDHOOD CARE AND EDUCATION IN THE CULTURAL CONTEXT OF AOTEAROA (NEW ZEALAND)}

\author{
Jenny Ritchie
}

VICTORIA UNIVERSITY OF WELLINGTON, NEW ZEALAND

Early childhood care and education in Aotearoa (New Zealand) has been celebrated through the international interest in the innovative sociocultural curriculum, Te Whäriki: He whäriki mätauranga mō ngā mokopuna o Aotearoa (New Zealand Ministry of Education, 1996). This document is now 20 years old, and is at the time of writing being updated by the New Zealand Ministry of Education. ${ }^{1}$ In this chapter, a brief overview of the historical and cultural contexts of early childhood care and education leads into a discussion of some key cultural constructs and values that are recognised in $T e$ Whäriki; in particular, those of the Indigenous people, the Māori. Discussion of the narrative assessment models that were developed to support the implementation of Te Whariki is followed by an outline of implications for teacher education. The chapter ends with some reflections on aspirations for the future of early childhood care and education in Aotearoa.

\section{Cultural and Historical Background to Early Childhood Education in Aotearoa}

In this section, the emergence of various early childhood care and education services in Aotearoa is considered against the particular historical, social, cultural, and political context of education in this country. Aotearoa is a Māori name for New Zealand, a former British colony in the South Pacific, comprising two large main islands, and inhabited by almost 4.7 million people, of whom the Indigenous Māori currently make up 14.9 per cent (Statistics New Zealand. Tatauranga Aotearoa, 2013). Māori are of Polynesian descent, and began their organised settlement of Aotearoa around the year 1200 (King, 2003).

Traditional Māori childrearing was a collective process, with responsibilities shared among whānau [extended family] members, both male and female, and with a special role for elders, who shared close relationships with their grandchildren (Jenkins \& Harte, 2011; Pere, 1982/1994). Māori children were treated respectfully and non-punitively (Jenkins \& Harte, 2011), which was viewed as indulgence by western observers (Salmond, 1991; Smith, 1995). Colonisation began with the arrival of British missionaries in 1814. In 1840, Māori chiefs and the British Crown signed the 'Treaty of Waitangi/Tiriti o Waitangi' in which the chiefs agreed to British settlement in exchange for promises to Māori of protection of their lands, villages and all other things of value to them, such as 
their language, as well as equal citizenship rights (Orange, 1987; Ward, 1991). Despite their initial faith in their Treaty partner to uphold this covenant, Māori quickly became a minority within their own country, succumbing to imported illnesses, being excluded from political power by the settler government, and suffering the loss of their languages and lands, along with traditional cultural and spiritual practices (Walker, 2004). This impact has been described as follows: 'Colonisation struck the Indigenous world with the destructive force of a massive comet, and its impact will be forever etched in the cultural memories of its entire people' (Anaru, 2012, p. 44). As the eminent New Zealand early childhood historian Helen May has written, 'the colonial period of missionary work, settlement, war and land acquisition is integral to an understanding of the later history of Māori early childhood education institutions' (May, 2015, p. 23).

The first European early childhood services were a network of infant schools for Māori children set up by British missionaries in the 1830s-40s, following the civilising mission and model of the early British infant schools of Samuel Wilderspin (May, 2015). May highlights the particular practice of renaming Māori children with English names, which can be read as a powerful symbol of colonising children's very identities, as was the missionary practice of removing children from their homes.

Services for young children remained patchy until the arrival of another European import, the Fröbellian kindergarten movement, which arrived in Aotearoa in the late 1880s. Once again these philanthropic endeavours held a civilising mission of 'rescuing' children, this time from the poverty of slum streets, as well as protecting the wider society from these perceived negative influences (May, 2015). This is illustrated in the aspiration outlined in the first report of the Dunedin Free Kindergarten Association in 1890: 'To guard the children of Dunedin from thriftlessness, disease, pauperism, and crime was the desire of those who first spoke of planning a kindergarten in this city' (as cited in May, 2015, p. 34). The first childcare provision, in the form of crèches attached to these early kindergartens, began around the same time and focused on supporting families with working parents, and one in particular, established by Mother Mary Aubert, also took care of abandoned infants. These services were stigmatised by association with immorality, and the patriarchal sensibility that caring for young children was the responsibility of their mothers. They were consequently less favoured by government than kindergartens, which were seen as educational and were thus supported financially and staffed by qualified teachers.

During World War II another service emerged in response to the particular needs of mothers. Playcentre, a parent cooperative, was strongly influenced by the progressive, democratic educational ideas of the New Education Fellowship/Foundation, whose proponents included Maria Montessori, Susan Isaacs, and John Dewey (Abiss, 1998; Campbell, 1938). In the early 1980s a further contextually responsive service emerged in response to the threatened death of the Māori language. This was Te Kōhanga Reo, a Māori-led movement that focused on ensuring that young Māori children would have access to te reo Māori, the Māori language, in their early years.

The late 1980s saw a further progressive shift in Aotearoa early childhood services, with the government moving to integrate the administration of all early childhood care and education services within the umbrella of the Ministry of Education, and establishing a benchmark three-year qualification for early childhood teachers. This meant that education policy recognised that all early childhood services provided both care and education. Unfortunately, it did not go as far as ensuring that qualified teachers in the 'childcare' sector would be paid the same salaries as those working in kindergartens. This remains an ongoing issue, as does the fact that kindergartens operating under the Kindergarten Federation (as opposed to private providers) ensure that all their teachers have a benchmark qualification, whilst in other education and care services, the government currently requires only a minimum of 50 per cent of teachers to be qualified.

Other progressive dimensions of the early childhood policy of the late 1980s were informed by the government-commissioned report, Education to be More (Meade, 1988), which highlighted the need for early childhood care and education in Aotearoa to include te reo Māori and tikanga Māori 
(Māori language and culture) as a characteristic of 'good quality' provision. This report led directly into the Labour government's flagship early childhood education policy, 'Before Five' (Lange, 1988). The then Prime Minister David Lange stated that his government saw early childhood education 'as having a priority among its social policies' (as cited in May, 2002, p. 6). Furthermore, in accordance with that government's social policy agenda, the 'Before Five' policy required that national guidelines which were to be drawn up for early childhood education would need to take account of the Treaty of Waitangi/Tiriti o Waitangi.

\section{Values, Cultures, and Communities of Aotearoa}

Early childhood care and education in Aotearoa draw upon some key philosophical premises that derive from its particular cultural and historical context. These include: recognition of the Indigenous people and their language, culture, values, and traditions; a strong egalitarian ethos; and a progressive sense of being responsive to particular contexts and needs. The key communities of Aotearoa are descended from several key groupings: the Indigenous peoples, the Māori; the original British (and later more broadly European) settlers; immigrants from South Pacific Islands; and Asia.

Aspects of egalitarianism and progressivism in New Zealand history can be located in the 1840 Treaty of Waitangi/Tiriti o Waitangi aspiration of equal citizenship to Māori, along with protection of their lands, language, and cultural values and practices. Yet this ethos did not necessarily translate into policies and provision for Māori (Nolan, 2007). In 1893, New Zealand was the first country to grant the vote to women. The 1877 Education Act established a free, secular and compulsory education system and in 1898, New Zealand also introduced a pension for the elderly. As a response to the hardships of the Great Depression of the 1930s, the first Labour government further cemented this ethos with provision for a 'cradle to grave' welfare state (Nolan, 2007). However, because of their marginalisation from influence within government, Māori have largely until recently been excluded from the design and implementation of social welfare provision, which has been modelled from the perspective of western individualism. This provision therefore failed to recognise or serve the collectivity that is at the heart of the Māori worldview (Stephens, 2015) and was also applied to Māori in a discriminatory manner (Derby, 2012; Walker, 2004).

Te ao Māori (the Māori worldview), like those of other Indigenous peoples, features a deep spiritual connection to the environment. In Māori cosmology, Ranginui (the Sky Father) and Papatūānuku (the Earth Mother) are the original parents from whom all living creatures descend. Thus, humans are cousins to plants, animals, insects, and birds. Each Māori tribe is distinguished by their links to their particular whenua (land) and its rivers, oceans, mountains, and the creatures who inhabit these. Māori see their role as being to exercise guardianship, kaitiakitanga, over all these elements within their domain. In addition to the obligation to exercise kaitiakitanga, other core values within the Māori worldview include kotahitanga (unity, collectivity, solidarity); manaakitanga (caring, hospitality, generosity); aroha (the obligation to care for others, particularly one's kin); wairuatanga (spiritual interconnectedness); and rangatiratanga and mana motuhake (leadership and self-determination) (Mead, 2003; Pere, 1982/94).

Māori were pro-active entrepreneurs in selectively pursuing benefits offered to their collective wellbeing via the relationships with the settlers and their culture, whilst still retaining their own sense of the importance of their beliefs, and maintaining their self-determination:

Maori did not passively receive Europe, but actively engaged with it. They chose, adjusted and repackaged the new, in many respects into a less culturally damaging form. They did so with courage and perceptiveness, exploiting a technologically formidable Europe that thought it was exploiting them, separating Europe and its things like a fool and his money. [For Maori] their goal was the immediate subtribal good.

(Belich, 1996, p. 154) 
Whilst the commitments made by the British Crown in the 1840 Treaty of Waitangi/Tiriti o Waitangi were widely disregarded by the New Zealand government for 135 years, in 1975 a new era of reconciliation was initiated by a Labour government with the promulgation of the Treaty of Waitangi Act of Parliament. For the past 40 years, Māori grievances for historical treaty breaches have slowly but steadily begun to be recognised and resolved. However, the ingrained racism and resentment of many Pākehā (those of European ancestry) continue to impede the project of decolonisation (Pack, Tuffin, \& Lyons, 2015).

It is fair to say, then, that the promises of the 1840 treaty are yet to be realised, and the intergenerational trauma of colonisation inflicted on Māori is yet to be healed (Pihama, Reynolds, Smith, Reid, Smith, and Te Nana, 2014). Māori continue to be over-represented in many negative social statistics, including poverty, high rates of imprisonment, youth suicide, poor health, and educational failure (Dale, O’Brien, \& St John, 2014). Recent research has found that teachers' poor expectations of Māori students continue to impede their success (Turner, Rubie-Davies, \& Webber, 2015). Clearly, pedagogy that emanates from a monocultural perspective will continue to perpetuate discriminatory outcomes.

People from South Pacific islands constitute 7.4 per cent of the population of Aotearoa (Statistics New Zealand, Tatauranga Aotearoa, 2013). The peoples of these islands share similar patterns of colonisation throughout the Pacific, in which missionaries have been influential. Those from the Samoan islands make up almost half (48.7 per cent) of the Pacific peoples living in Aotearoa, with those from the Cook Islands comprising 20.9 per cent, Tonga 20.4 per cent, and Niue 8.1 per cent. People from the Cook Islands, Niue, and Tokelau hold New Zealand citizenship, and are therefore free to live and work in Aotearoa. New Zealand immigration policies have at times, such as during the 1960s and 70s, encouraged waves of immigration from various Pacific Islands in order to supply workers for the unskilled labour force. Remittances from family members living in Aotearoa contribute significantly to the wellbeing of families who remain in the home islands. Issues pertaining to the retention of home languages and cultural practices become increasingly of concern as successive generations are born and spend their lives in New Zealand. Whilst each of these different island groups have their own languages and cultural values, they share some commonalities with each other as well as with Māori, such as a deeply spiritual collectivist ethos.

A more recent era of demographic change in Aotearoa is the opening up of immigration policies resulting in a surge of immigration from a wide range of different ethnicities, to the point that New Zealand is now officially recognised as a 'superdiverse' country (Royal Society of New Zealand, 2013; Spoonley, 2015). The implications for education of this shift are only beginning to be examined (Spoonley, 2015). However, an examination of recent research in the early childhood care and education sector has raised concerns about the demonstrable failure of teachers to move beyond monocultural discourses despite expectations of the curriculum for partnership with Māori families signalling that challenges exist in meeting the pedagogical needs of an increasingly ethnically diverse sector (Chan \& Ritchie, 2016).

A number of Pacific Islands face severe threats from the sea level rising due to global warming. It is increasingly likely that future waves of immigration to Aotearoa may comprise climate change re-settlers (Lawler, 2011). Again, for these families, retention of language and particular cultural practices will be an issue (Cameron, 2014).

\section{Te Whāriki: The New Zealand Early Childhood Curriculum}

With its promulgation in 1996, Te Whäriki offered an innovative, even radical, treatment of the notion of an early childhood education curriculum (Nuttall, 2003, 2013). Focusing inclusively on the age-group from birth to the early years of school, and applicable to all the various and diverse early childhood care and education services, it used a sociocultural theoretical lens which diverged 
from the more purely developmental approaches of other western models. Furthermore, it was avowedly 'bicultural' in its design process, structure, and content, stipulating that 'all children should be given the opportunity to develop knowledge and an understanding of the cultural heritages of both partners to Te Tiriti o Waitangi' (New Zealand Ministry of Education, 1996, p. 9). The two 'partners' in this treaty context are Māori, as the 'tangata whenua', the original inhabitants of this land, and 'tangata tiriti', all those who now reside in the country due to the antecedent of the treaty having allowed for non-Indigenous settlement (Durie, as cited in King, 2003, p. 191).

Te Wharriki means literally 'the woven flax mat'. This metaphor symbolises the writers' expectation that the overarching principles and related strands and goals outlined in the document would serve as the flexible and dynamic components whereby each different early childhood setting could weave its own version of an early childhood curriculum, in response to their particular community and context (May, 2001). Te Whâriki was informed by a Māori conceptual framework contributed by Tilly and Tamati Reedy, who were contracted by the Te Kōhanga Reo National Trust to work alongside early childhood studies scholars Helen May and Margaret Carr, of the University of Waikato. This model of partnership between Māori and Pākehā writers is significant, as it reflects the Treaty of Waitangi/Tiriti o Waitangi premise of an equal relationship between these two parties. This partnership model has the potential to deliver on the treaty promise of protection of Māori language, cultural practices and spiritual beliefs, and this is reflected in the structure and content of Te Whariki. The document is underpinned by four foundational principles or kaupapa whakahaere, which are strongly informed by and reflective of key Māori conceptualisations: Whakamana - Empowerment; Kotahitanga - Holistic Development; Whānau Tangata - Family and Community; and Ngā Hononga - Relationships. It should be noted, however, that the Māori and English terms are not direct translations of each other (see Figure 16.1).

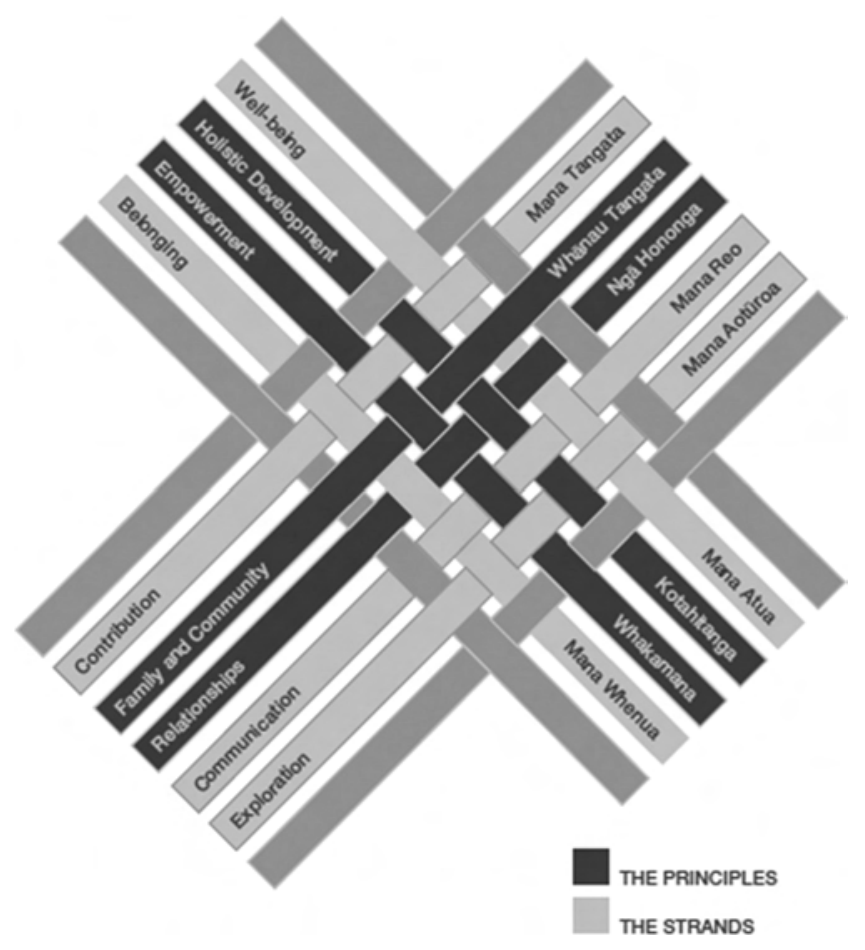

Figure 16.1 The woven whāriki (Ministry of Education, 1996, p. 13) 
Building on the foundation laid by these principles are the six 'strands' of Te Whāriki: Mana Atua - Wellbeing; Mana Whenua - Belonging; Mana Tangata - Contribution; Mana Reo Communication; and Mana Aotūroa - Exploration. Each of these strands contains a range of goals, and for each goal there are a number of illustrative learning outcomes, as well as some "questions for reflection' which are intended to foster the reflexivity required by teachers working with this complex document.

The demands of the reflexivity and complexity in programme design and implementation posed by such a curriculum were furthermore compounded in that at the time that Te Whariki was introduced to the sector (1996), only 'the person in charge' of the early childhood setting was required to hold a recognised qualification. Despite the intentions of the subsequent Labour-led government's 2002 early childhood strategic plan to remedy this situation in a graduated fashion (New Zealand Ministry of Education, 2002), the current National-led government in 2008 reduced this expectation to a minimum requirement of 50 per cent of staff needing to be qualified. Incredibly, services such as the kindergarten movement, who choose to maintain a 100 per cent level of qualified staffing, are actually financially penalised by the current funding system (Macdonald, 2015). This government's early childhood policy is focused on increasing early childhood participation, without simultaneously ensuring that the financial supports are in place to ensure high-quality provision (Ritchie, Harvey, Kayes, \& Smith, 2014).

A core aspect of Te Whăriki, its 'bicultural' expectations, continue to pose a challenge to a workforce which is largely not Māori, since very few non-Māori are fluent speakers of te reo Māori, the Māori language, or have a deep understanding of Māori cultural values and practices. Māori are bicultural, in that they are immersed in the modes and norms of the dominant, Pākehā (western) culture, and 21.3 per cent speak Māori as well as English, and are therefore also bilingual (New Zealand Ministry of Social Development, 2016). The Education Review Office (ERO), which evaluates the practices of education settings in Aotearoa New Zealand, has been repeatedly critical of centre provision in relation to inclusive practices for tamariki and whānau Māori (Māori children and families) (Education Review Office, 2004, 2008a, 2010, 2012, 2013). A 2004 report, Catering for Diversity in Early Childhood Services (Education Review Office, 2004), noted that in responding to the needs of diverse families, programming needed 'to move beyond tokenism to a deeper understanding of how service provision impacts on different cultures' (p. 16). This report also signalled that the capacity for teachers to move beyond a monocultural frame, initially in supporting Māori children and families, could effectively be extended to respond to families of other ethnic backgrounds:

There was a strong correlation between the quality of provision of te reo and tikanga Māori and the provision for the differing cultures of families contributing to services. Rather than biculturalism and multiculturalism being alternatives, it appears that attention to one had positive benefits for the other.

(Education Review Office, 2004, p. 11)

Subsequent research has indicated that this cultural responsiveness remains a challenge for many teachers, who often prefer to remain within their habitual discourses and practices, and fail to step out of their comfort zones to initiate and build strong relationships with families from cultural backgrounds other than their own (Chan \& Ritchie, 2016). This is despite the ongoing efforts of researchers to illuminate such possibilities (Podmore, Hedges, Keegan, \& Harvey, 2015; Ritchie \& Rau, 2006, 2008). Research has shown that when teachers make visible efforts to value and include Māori language, along with cultural symbols and practices, Māori children and their families are receptive to and greatly appreciative of this provision (Ritchie \& Rau, 2006, 2008). Māori teachers are often at the forefront of leading the transformation of programmes from being monocultural, to being culturally relevant (Rau, 2007). 
In addition to the historical factors of colonialist embedded racism, two of the contemporary factors that compound these efforts towards implementation of the Te Whāriki aspirations for cultural validation are the low minimum requirement for qualified teachers, and the lack of governmentfunded professional learning opportunities for in-service teachers.

\section{Research on Assessment of Early Childhood Care and Education Programmes}

Despite international trends and pressure towards normativising, standards-based assessment, the early childhood care and education sector in Aotearoa New Zealand, in line with Te Whäriki, follows two models of narrative assessment for which the Ministry of Education has provided exemplar documents (New Zealand Ministry of Education, 2004, 2007, 2009a, 2009b). Kei Tua o te Pae comprises a series of 20 booklets of exemplars (New Zealand Ministry of Education, n.d.), along with a research-based rationale for each, on topics such as: sociocultural assessment; bicultural assessment; children contributing to their own assessment; and assessment for infants and toddlers. Te Whatu Pōkeka (New Zealand Ministry of Education, 2009) provides a rational, philosophical outline and exemplars of assessment models grounded in te ao Māori (a Māori worldview).

The contract to develop the early childhood assessment model Kei Tua o te Pae was led by Margaret Carr, one of the writers of Te Wharriki. This enabled a degree of continuity of the philosophy and wisdom that Te Wharriki embodies. The promotion of narrative assessment, which is similar to what is elsewhere referred to as pedagogical documentation (Pacini-Ketchabaw, 2010), avoids the narrow focus on assessing children's particular skills or discrete knowledge components, by adopting a holistic, contextual, child-centred focus on children's interests, dispositions, working theories and learning strategies. As Arndt and Tesar have recently written:

Rather than focusing on a particular truth, singular category of development, or outcome, early childhood assessment practices in Aotearoa New Zealand have more recently promoted opening up to possibilities of many truths, and to children's learning and abilities as often fluctuating and unpredictable. This focus sees children's lives and development as always entwined in intricately woven relational webs, with their peers, their physical surroundings, their teachers, families and wider communities.

(Arndt \& Tesar, 2015, p. 72)

The Kei Tua o te Pae booklets contain a multitude of 'learning story' exemplars, which offer rich pictures of children's learning, as seen through the eyes and voices of their teachers, and sometimes also parents, as they 'notice, recognise and respond' to children's learning. Fostering dispositions for learning is recognised in Te Whäriki as being a key pedagogical task. In Kei Tua o te Pae, dispositions are viewed as the mechanism whereby children are able to develop their own working theories, thus turning their inherent capacity for learning into demonstrable learning outcomes (Booklet 10, Ministry of Education, 2007). The learning dispositions highlighted in Kei Tua o te Pae are: taking an interest; being involved; persisting with difficulty, challenge and uncertainty; expressing a point of view or feeling; and taking responsibility (New Zealand Ministry of Education, n.d.). Whilst Te Wharriki focuses strongly on involving parents and families in assessing children's learning, it further stipulates that:

Children's self-assessment can inform adults' assessment of learning, development, and the environment by providing insights that adults may not have identified and by highlighting areas that could be included or focused on for assessment. Children may also help to decide what should be included in the process of assessing the programme and the curriculum.

(New Zealand Ministry of Education, 1996, p. 30) 
However, despite these aspirations, a national evaluation by the Education Review Office in 2008 expressed concerns about the extent to which children's, parents', and families' / whānau voices were included in early childhood assessment processes:

A particular issue was the lack of meaningful participation of children, parents and whānau in assessment of children's learning and development. In almost two thirds of the services children did not contribute to assessment, and in about half the services, educators did not give children opportunities to revisit and reflect on their learning. Similarly, in about half the services, parents and whānau were not meaningfully involved in assessment practice.

(Education Review Office, 2008b, p. 40)

It appears that as with the operationalising of the 'bicultural' nature of Te Whăriki, this inclusive, collective model of assessment similarly faces challenges in its realisation.

The second model of early childhood assessment, Te Whatu Pōkeka, was developed in consultation with a collective of teachers from Māori early childhood care and education settings. One of the developers of Te Whatu Pōkeka signals that the cultural locatedness and impact of assessment

draws upon kaupapa Kaupapa ${ }^{2}$ Māori theory and traditional Māori world views, values, and concepts in order to articulate assessment understandings and framings that express Māori ways of knowing and being and valued learnings. It is premised upon the idea that cultural contexts, values, and understandings contribute significantly to children's learning and potential growth, and that assessment is a vehicle for acknowledging, reifying, and normalising this cultural capital.

(Rameka, 2014, p. 36)

Key Māori constructs such as whakapapa (genealogical interconnectedness) and wairuatanga (spiritual interconnectedness) underpin kaupapa Māori assessment (Paki, 2007; Rameka, 2012). Teachers using a Māori worldview as the foundation for their 'assessment' practices were able to re-think even the terminology of 'assessment', reframing this as, for example, 'writing a time in a child's life' (as cited in Rameka, 2014). They also reconceptualised the 'audience' of their assessment, focusing their writing on the child's whānau (extended family), which they saw as inclusive of the child as well as grandparents (and other family members). This resulted in narratives that were described as having a 'wow factor' for the whānau, in that they were celebratory of the child's milestones and achievements.

Dispositions, as mentioned earlier, are a key focus of the narrative approach of Te Whariki. The Māori teachers involved in the development of Te Whatu Pōkeka found it more relevant to locate children's dispositions in a Māori worldview. Teachers from one centre identified the following culturally valued qualities, as displayed by the legendary demi-God Māui, as ones that they wanted to acknowledge in their children:

Mana: identity - pride - inner strength

Manaakitanga/aroha: caring - sharing - kindness - supporting others - being a friend

Whakakata: humour - fun

Tinihanga/whakatoi: cunning - trickery - cheekiness

Pātaitai/kaitoro: testing - challenging - questioning - curiosity - exploring - risk-taking

Arahina/māiatanga: confidence - self-reliance - leadership - perseverance - self-assurance

Māramatanga: developing understandings - working through difficulty - lateral thinking

Ngā hononga: tuakana-teina - ako - whanaungatanga.

(New Zealand Ministry of Education, 2009, p. 12) 
In a similar vein, Pauline Luafutu-Simpson (2011) worked with Samoan and other Pacific Islands' early childhood education colleagues to identify an authentic Samoan assessment lens, in order to address issues regarding the lack of engagement by Pacific Islands' early childhood teachers with the Kei Tua o te Pae model of assessment. The following is the list of dispositions that emanated from her project, a framework which she calls the Fale Tele, and which she emphasises is not intended to be definitive:

- fa'amaoni [dependable/loyal/faithful]

- onosai [patience]

- mata ataata [cheerfulness]

- fa'apalepale [restraint]

- tauivi [to persevere]

- loto taumafai [willingness to try]

- loto fesoasoani [helpful - caring]

- finau [determined/to advocate]

- ava [honour]

- loto maulalo [humility]

- agamalu [of a peaceful nature]

- loto foai [giving]

- loto toa [courageous/confident]

- mataatata [cheerful]

- gaioi [active, energetic]

- agava'a [competent, skilled]

- faamalosi [empowerment].

(Luafutu-Simpson, 2011)

These examples demonstrate the richness that emanates from approaches to assessment that are derived from a cultural locatedness and that thus reflect culturally valued attributes. In both the Whatu Pokeka and Fale Tele models, teachers are able to celebrate the children's identities and characteristics as Māori or Samoan. These culturally located identities are connected via genealogy with ancestors and tribal histories, anchoring children's learning in these contexts, and thus evoking deeper meanings and understandings for teachers, parents and family members who are mindful of these connections.

\section{Quality Practices and Outcomes for Children}

These narrative, culturally grounded models of assessment, having moved beyond the bounds of western psychometric and developmentalist models of measuring children's progress in relation to specific social and cognitive outcomes, have been challenged by some who would prefer standardised methods (e.g., Blaiklock, 2013). Definitions of 'quality' are subjective, however, between different nations, populations, communities and even services within the same country, and the models of curriculum implementation and assessment being implemented in Aotearoa reflect a recognition of this (OECD, 2012; Taguma, Litjens, \& Makowiecki, 2012). Rather than expecting children to be measured by and measure up to a set of pre-determined standards, the approach taken in Aotearoa New Zealand is based in the view that: 'All children should experience an early learning curriculum that is responsive to their language, culture, identity, strengths, interests, needs and abilities' (Education Review Office, 2016, p. 5).

Work done within the OECD 'Starting Strong' project has recognised the value of the Aotearoa New Zealand model of curriculum: 
New Zealand's Te Whāriki is a progressive and cogent document regarding the orientation and aims of ECE. The document clearly lays out what is expected from staff and child development with useful examples. The curriculum provides continuous child development through the use of one national framework for ECE; putting the community at the centre of the curriculum; strongly focusing on wellbeing and learning; ensuring age-appropriate content; emphasising the importance of tolerance and respect for cultural values and diversity; and aligning the ECE curriculum with primary schooling.

(Taguma et al., 2012, p. 7)

A recent national synthesis report from the New Zealand Education Review Office (ERO) also recognises the strengths of Te Wharriki, whilst also highlighting that the open-ended, contextually responsive and complex nature of the curriculum creates particular challenges in relation to delivering high-quality practice:

The depth and richness of Te Whāriki is internationally recognised; however, the holistic and interpretive nature of this curriculum document is both its strength and a challenge. ERO's evaluations signal the need for increased support for the early childhood sector to work with the full intent of Te Whāriki as part of their curriculum design and implementation.

(Education Review Office, 2016, p. 44)

In as much as ' $[\mathrm{h}]$ igher qualifications are found to be strongly associated with better child outcomes' (OECD, 2012, p. 11), a range of other factors have also been identified. Skilled pedagogical knowledge and leadership, teachers' intentionality and a reflective orientation, their knowledge of Te Wharriki and subject content knowledge, as well as their commitment and skills in developing good relationships with parents and whānau (extended families) are aspects intrinsic to teachers' professional dispositions, knowledge and competence. The capacity to operationalise these aspects is integrally dependent upon their working conditions and salaries, supportive management, optimum ratios of teachers to children, small group sizes and opportunities for ongoing professional learning. These are all factors contributing to high-quality, culturally responsive practice which is likely to deliver excellent outcomes for children (Education Review Office, 2016; OECD, 2012). Teacher education programmes have a key role to play in this context.

\section{Teacher Education and Implications for Early Childhood Care and Education}

Early childhood teacher education qualifications in Aotearoa are offered by a diverse mix of 16 public providers (seven universities, two whare wānanga (Māori universities)) and seven institutes of technology, along with three private providers - a total of 19 different providers. Qualifications offered include a three-year Bachelor's degree, one-year graduate diplomas and one-year Master's-level teaching degrees. Each qualification is approved, monitored and reviewed by the Education Council Aotearoa New Zealand (EDUCANZ), formerly known as the New Zealand Teachers Council.

The Education Council provides a set of graduating teachers' standards (New Zealand Teachers Council/Education Council, 2007), which initial teacher education providers are to use within their teacher education programme, with the expectation that each graduating teacher will, during the course of her/his studies, have demonstrated her/his competence with regard to each standard. Standard number three, in particular, focuses on the sociocultural context of teaching in Aotearoa, stating that graduating teachers should 'understand how contextual factors influence teaching and learning: 
a have an understanding of the complex influences that personal, social and cultural factors may have on teachers and learners

b have knowledge of tikanga and te reo Māori [the Māori culture and language] to work effectively within the bicultural contexts of Aotearoa New Zealand

c have an understanding of education within the bicultural, multicultural, social, political, economic and historical contexts of Aotearoa New Zealand'.

(New Zealand Teachers Council/Education Council, 2007, p. 1)

These statements are clearly aspirational, given the history of colonisation and the ongoing monoculturalism of the dominant Pākehā [of European descent] majority of the population. As noted earlier, Māori make up 14.9 per cent of the overall population, but only 21.3 per cent of Māori speak their own language well enough to hold a conversation in that language. Of the overall population of the country, only 3.7 per cent can do so (New Zealand Ministry of Social Development, 2016). Thus, the sustainability of the Māori language remains in question. This needs to be supported by both government policy and the wider community, and cannot be left to Māori alone, as the linguist Richard Benton (2015) has noted.

This highlights a serious challenge for teacher education providers, in that they are faced with the task of enhancing the capacity of students, the majority of whom are monolingual English speakers, to be able to speak and teach the Māori language. I noted this concern whilst conducting my doctoral research (Ritchie, 1999), and again after further research ten years later (Ritchie, 2009), and now with the proliferation of one-year teaching qualifications this has become even more of a concern.

More broadly, concerns also remain about low teacher expectations for Māori and also children of Pacific Islands backgrounds (Turner, Rubie-Davies, \& Webber, 2015) which are reminiscent of earlier research findings (Simon, 1990). It seems that racist attitudes, whilst not necessarily overt, do remain entrenched, and continue to impact the life-chances of those who are not members of the privileged majority culture. Again, this is a major issue and ongoing challenge for teacher education providers.

\section{Future Directions and Policies}

As I write this chapter Te Wharriki is in the process of being 'updated' by the Ministry of Education. It appears that this update is not being conducted in the spirit of the original development process in the early 1990s, which involved extensive engagement and consultation with a wide cross-section of the sector. The extent and nature of this update are at this point indeterminate.

It is to be hoped that in the future our sector will be able to continue working towards realisation of the vision of Te Whäriki as a sociocultural, 'bicultural', culturally responsive, child-centred, and whānau/family inclusive model of early childhood education and care. Government policy to support this process would include a return to the expectation that all teachers in the sector hold a degree-level qualification. Furthermore, all teachers who hold such qualifications, whether they work in education and care settings or kindergartens, should be paid on the same scale. In the long term, if our education policy is changed to make learning the Māori language compulsory within primary and secondary schools, it would be less of a challenge for teacher education providers to foster competence in te reo within the constraints of the teacher education programme. A quarter of a century ago a draft New Zealand languages policy pointed out that our country was unusual in its monolingualism (Waite, 1992). More recently, a 2013 New Zealand Royal Society report returned to this motif, again pointing out the many benefits of multilingualism, which include meta-cognitive advantages, positive cultural identity for Indigenous (and other) people who speak their own language(s) and social harmony, and renewing the earlier call for a national languages policy. These issues of language and cultural identity retention will be further exacerbated if New Zealand is besieged in the future with climate change re-settlers from nearby small island nations. Currently, there are several neighbouring islands such as Kiribati, Tuvalu, the Solomons, and the Marshall 
Islands that are currently threatened by sea-level rise which is jeopardising the fresh water supply of the inhabitants (Cameron, 2014; Purvis, 2016).

Lastly, the early childhood care and education sector in Aotearoa has, up to this point, remained free of externally imposed standardised measurement, which has been inflicted on the primary education sector, with negative impacts (Thrupp, 2014; Thrupp \& Easter, 2013). The current narrative assessment models being employed offer potential to deliver rich, nuanced, contextualised pictures of children's learning over time. Imposing standardised assessment measures risks a narrowing of the curriculum and the labelling of children, both of which are educationally detrimental. It is to be hoped that in the future early childhood care and education teachers in Aotearoa will be further enabled, with a return to government-funded ongoing in-service professional learning provision, to build on the strengths of Te Whäriki, Kei Tua o te Pae and Te Whatu Pōkeka, and thus continue to reflect and support the diversity and texture of the communities in which they work.

\section{Notes}

1 A revised version of Te Whäriki has subsequently been published.

2 Kaupapa Māori is theory and/or practice informed from a Māori philosophical perspective.

\section{References}

Abiss, J. (1998). The 'New Education Fellowship' in New Zealand: Its activity and influence in the 1930s and 1940s. New Zealand Journal of Educational Studies, 33(1), 81-93.

Anaru, N. (2012). Deep impact and the tail of colonialism. Te Kaharoa, 5(1), 43-68.

Arndt, S., \& Tesar, M. (2015). Early childhood assessment in Aotearoa New Zealand: Critical perspectives and fresh openings. Journal of Pedagogy, 6(2), 71-86. DOI: 10.1515.

Belich, J. (1996). Making Peoples: A History of the New Zealanders from Polynesian Settlement to the End of the Nineteenth Century. Auckland: Penguin.

Benton, R. A. (2015). Perfecting the partnership: Revitalising the Māori language in New Zealand education and society 1987-2014. Language, Culture and Curriculum, 28(2), 99-112. DOI: 110.1080/07908318.07902 015.01025001.

Blaiklock, K. (2013). What are children learning in early childhood education in New Zealand? Australasian Journal of Early Childhood, 38(2), 51-56.

Cameron, J. (2014). Dreams From Kiribati: Maintaining Identity and Social Resilience Post-Migration. Unpublished Master's of Environmental Studies thesis. Wellington: Victoria University of Wellington. Retrieved from https://researcharchive.vuw.ac.nz/handle/10063/4864.

Campbell, A. E. (1938). Modern Trends in Education: The Proceedings of the New Education Fellowship Conference held in July, 1937. Wellington: Whitcombe and Tombs.

Chan, A., \& Ritchie, J. (2016). Parents, participation, partnership: Problematising New Zealand early childhood education. Contemporary Issues in Early Childhood, 17(3), 289-303.

Dale, M. C., O’Brien, B., \& St John, S. (2014). Our Children, Our Choice: Priorities for Policy. Auckland: Child Poverty Action Group. Retrieved from www.cpag.org.nz/resources-publications/our-children-our-choicepriorities-for-policy-7.

Derby, M. (2012). Story: Veterans' Assistance. War Pensions. Wellington, NZ: Te Ara - the Encyclopedia of New Zealand. Retrieved from www.teara.govt.nz/en/veterans-assistance/page-1.

Education Review Office. (2004). Catering for Diversity in Early Childhood Services. Wellington Education Review Office.

Education Review Office. (2008a). Māori Children in Early Childhood: Pilot Study. Wellington: Education Review Office.

Education Review Office. (2008b). The Quality of Assessment in Early Childhood Education. Wellington: Education Review Office. Retrieved from www.ero.govt.nz/publications/the-quality-of-assessment-in-early-childhood-education.

Education Review Office. (2010). Success for Māori Children in Early Childhood Services. Wellington: Education Review Office. Retrieved from www.ero.govt.nz/publications/success-for-maori-children-in-early-childhood-services.

Education Review Office. (2012). Partnership with Whānau Māori in Early Childhood Services. Wellington: Education Review Office. Retrieved from www.ero.govt.nz/National-Reports/Partnership-with-WhanauMaori-in-Early-Childhood-Services-Feb-2012. 
Education Review Office. (2013). Working with Te Whäriki. Wellington: Education Review Office. Retrieved from www.ero.govt.nz/publications/working-with-te-whariki.

Education Review Office. (2016). Early Learning Curriculum: What's Important and What Works. Wellington: Education Review Office. Retrieved from www.ero.govt.nz/publications/early-learning-curriculum.

Jenkins, K., \& Harte, H. M. (2011). Traditional Maori Parenting: An Historical Review of Literature of Traditional Maori Child Rearing Practices in Pre-European Times. Auckland: Te Kahui Mana Ririki. Retrieved from www. ririki.org.nz/research/our-research.

King, M. (2003). The Penguin History of New Zealand. Auckland: Penguin.

Lange, D. (1988). Before Five: Early Childhood Care and Education in New Zealand. Wellington: Department of Education.

Lawler, J. (2011). Children and Climate Change: Children's Vulnerability to Climate Change and Disaster Impacts in East Asia and the Pacific. Bangkok: UNICEF East Asia and Pacific Regional Office. Retrieved from: www. unicef.org/malaysia/children_and_climate_change.pdf.

Luafutu-Simpson, P. (2011). Exploring the Teaching of Effective Approaches for Assessing Young Samoan Children's Learning in Early Childhood Centres: Developing an Authentic Samoan Lens. Wellington: Ako Aotearoa. National Centre for for Tertiary Teaching Excellence. Retrieved from https://akoaotearoa.ac.nz/ako-hub/ ako-aotearoa-southern-hub/resources/pages/developing-authentic-samoan-lens.

Macdonald, L. (2015). Kindergartens Face Job Cuts Over Low Funding. Auckland: Newshub. Retrieved from www. newshub.co.nz/nznews/kindergartens-face-job-cuts-over-low-funding-2015101517\#axzz4HLu1SNhL.

May, H. (2001). Politics in the Playground: The World of Early Childhood in Postwar New Zealand. Wellington: Bridget Williams Books and New Zealand Council for Educational Research.

May, H. (2002). Early childhood care and education in Aotearoa - New Zealand: An overview of history, policy and curriculum. Paper for Publication in McGill Journal of Education. Retrieved from www.aeufederal. org.au/Ec/HMayspeech.pdf.

May, H. (2015). Nineteenth-century early childhood institutions in Aotearoa New Zealand: Legacies of enlightenment and colonisation. Journal of Pedagogy, 6(2), 21-39.

Mead, H. M. (2003). Tikanga Māori: Living by Māori Values. Wellington: Huia.

Meade, A. (1988). Education to Be More: Report of the Early Childhood Care and Education Group. Wellington: Government Printer.

New Zealand Ministry of Education. (1996). Te Whāriki: He whāriki mātauranga mō ngā mokopuna o Aotearoa: Early childhood curriculum. Wellington: Learning Media. Retrieved from www.education.govt.nz/early-childhood/ teaching-and-learning/ece-curriculum/te-whariki.

New Zealand Ministry of Education. (2002). Pathways to the Future: Ngā Huarahi Arataki: A 10-Year Strategic Plan for Early Childhood Education. Wellington: Ministry of Education.

New Zealand Ministry of Education. (2004, 2007, 2009a). Kei Tua o te Pae: Assessment for Learning: Early Childhood Exemplars. Wellington: Learning Media.

New Zealand Ministry of Education. (2009b). Te Whatu Pōkeka: Kaupapa Māori Assessment for Learning. Early Childhood Exemplars. Wellington Learning Media. Retrieved from www.education.govt.nz/assets/ Documents/Early-Childhood/TeWhatuPokeka.pdf.

New Zealand Ministry of Education. (2016). Teach NZ: Thinking of Teaching? Wellington: New Zealand Ministry of Education. Retrieved from www.teachnz.govt.nz/thinking-of-teaching/qualifications-information-for-2017/ early-childhood-education/QualificationSearchForm.

New Zealand Ministry of Education. (n.d.). Kei Tua o te Pae. Wellington: Ministry of Education. Retrieved from www.education.govt.nz/early-childhood/teaching-and-learning/kei-tua-o-te-pae-2.

New Zealand Ministry of Social Development. (2016). The Social Report. Wellington: Ministry of Social Development. Retrieved from http://socialreport.msd.govt.nz.

New Zealand Teachers Council/Education Council. (2007). Graduating Teacher Standards: Aotearoa New Zealand. Wellington: New Zealand Teachers Council. Retrieved from http://educationcouncil.org.nz/content/ graduating-teacher-standards.

Nolan, M. (2007). The reality and myth of New Zealand egalitarianism: Explaining the pattern of a labour historiography at the edge of empires. Labour History Review, 72(2), 113-134.

Nuttall, J. (Ed.). (2003). Weaving Te Whäriki: Aotearoa New Zealand's Early Childhood Curriculum Document in Theory and Practice. Wellington: NZCER.

Nuttall, J. (Ed.). (2013). Weaving Te Whäriki: Aotearoa New Zealand's Early Childhood Curriculum Document in Theory and Practice (2nd ed.). Wellington: NZCER Press.

OECD. (2012). Starting Strong III: A Quality Toolbox for ECEC. Retrieved from www.oecd.org/edu/ school/49325825.pdf.

Orange, C. (1987). The Treaty of Waitangi. Wellington: Allen and Unwin/Port Nicholson Press. 


\section{Jenny Ritchie}

Pacini-Ketchabaw, V. (Ed.). (2010). Flows, Rhythms, and Intensitites of Early Childhood Education Curriculum. New York: Peter Lang.

Pack, S., Tuffin, K., \& Lyons, A. (2015). Resisting racism: Māori experiences of interpersonal. Racism in Aotearoa New Zealand. AlterNative: An International Journal of Indigenous Peoples, 11(3), 269-282.

Paki, V. (2007). Kimihia, rangahaua ngā tikanga heke iho: He taonga huahua e riro mai. Exploring whakapapa as a tool towards a Kaupapa Māori assessment framework in early childhood education (Master's in Education). University of Waikato, Hamilton.

Pere, R. R. (1982/94). Ako: Concepts and Learning in the Maori Tradition. Hamilton: Department of Sociology, University of Waikato. Reprinted by Te Kohanga Reo National Trust Board.

Pihama, L., Reynolds, P., Smith, C., Reid, J., Smith, L. T., \& Te Nana, R. (2014). Positioning historical trauma theory within Aotearoa New Zealand. AlterNative: An International Journal of Indigenous Peoples, 10(3), $248-262$.

Podmore, V. N., Hedges, H., Keegan, P. J., \& Harvey, N. (2015). Children Who Learn in More Than One Language: Early Childhood Teachers Afloat in Plurilingual Seas. Wellington: Teaching and Learning Research Initiative.

Purvis, K. (2016). Sinking states: The islands facing the effects of climate change. The Guardian. Retrieved from www.theguardian.com/global-development-professionals-network/gallery/2016/feb/15/pacific-islandssinking-states-climate-change.

Rameka, L. (2012). Whakapapa: Culturally valid assessment in early childhood. Early Childhood Folio, 16(2), 33-37.

Rameka, L. (2014). He huarahi aromatawai: Assessment journeys. Early Childhood Folio, 18(1), 35-40.

Rau, C. (2007). Shifting paradigms: Māori women at the interface of Te Tiriti (treaty)-based early childhood education in Aotearoa. Childrenz Issues, 11(1), 33-36.

Ritchie, J. (1999). The use of Te Reo Mäori in early childhood centres. Early Education, 20(Winter), 13-21.

Ritchie, J. (2009). He Taonga Te Reo: Honouring te reo me ona tikanga, the Māori language and culture, within early childhood education in Aotearoa. In S. May (Ed.), LED2003: Refereed Conference Proceedings of the 1st International Conference on Language, Education and Diversity. Wilf Malcolm Institute of Educational Research, (CD-Rom ed.). Hamilton: University of Waikato.

Ritchie, J., \& Rau, C. (2006). Whakawhanaungatanga: Partnerships in Bicultural Development in Early Childhood Education. Final Report to the Teaching \& Learning Research Initiative Project. Wellington: Teaching Learning Research Institute. Retrieved from www.tlri.org.nz/tlri-research/research-completed/ece-sector/ whakawhanaungatanga\%E2\%80\%94-partnerships-bicultural-development.

Ritchie, J., \& Rau, C. (2008). Te Puawaitanga: Partnerships with Tamariki and Whānau in Bicultural Early Childhood Care and Education. Final Report to the Teaching Learning Research Initiative. Wellington: Teaching Learning Research Institute. Retrieved from www.tlri.org.nz/tlri-research/research-completed/ece-sector/ te-puawaitanga-partnerships-tamariki-and-wh\%C4\%81nau.

Ritchie, J., Harvey, N., Kayes, M., \& Smith, C. (2014). Our Children, Our Choice: Priorities for Policy. Child Poverty Action Group Policy Paper Series. Part Two: Early Childhood Care \& Education (ECCE). Auckland: Child Poverty Action Group. Retrieved from www.cpag.org.nz/resources-publications/ our-children-our-choice-priorities-for-policy-7.

Royal Society of New Zealand. (2013). Languages in Aotearoa New Zealand. Wellington: Royal Society of New Zealand. Retrieved from www.royalsociety.org.nz/expert-advice/information-papers/yr2013/ languages-in-aotearoa-new-zealand.

Salmond, A. (1991). Two Worlds: First Meetings Between Mäori and Europeans, 1642-1772. Auckland: Viking.

Simon, J. (1990). 'Good intentions, but . . . In R. Steele (Ed.), Whakamana Tangata: A Beginner's Guide to Cultural Identity (pp. 44-48). Wellington: Ministry of Education.

Smith, L. T. (1995). The colonisation of Māori children. Youth Law Review, August/September/October, 8-11.

Spoonley, P. (2015). New diversity, old anxieties in New Zealand: The complex identity politics and engagement of a settler society. Ethnic and Racial Studies, 38(4), 650-661. DOI: 610.1080/01419870.01412015.0 1980292.

Statistics New Zealand. Tatauranga Aotearoa. (2013). 2013 Census Quickstats about Culture and Identity. Wellington: Statistics New Zealand. Tatauranga Aotearoa. Retrieved from www.stats.govt.nz/Census/2013census/profile-and-summary-reports/quickstats-culture-identity.aspx.

Stephens, M. (2015). 'To work out their own salvation': Māori constitutionalism and the quest for welfare. Victoria University of Wellington Law Review, 46, 907-936.

Taguma, M., Litjens, I., \& Makowiecki, K. (2012). Quality Matters in Early Childhood Education and Care. New Zealand 2012. Paris: Organisation for Economic Co-operation and Development (OECD).

Thrupp, M. (2014). At the eye of the storm: Researching schools and their communities enacting National Standards. New Zealand Journal of Educational Studies, 49(1), 6-20. 
Thrupp, M., \& Easter, A. (2013). 'Tell me about your school': Researching local responses to New Zealand's National Standards policy. Assessment Matters, 5, 94-115.

Turner, H., Rubie-Davies, C. M., \& Webber, M. (2015). Teacher expectations, ethnicity and the achievement gap. New Zealand Journal of Educational Studies, 50(1), 55-69.

Waite, J. (1992). Aoteareo: Speaking for Ourselves. A Discussion on the Development of a New Zealand Languages Policy. Wellington: Learning Media.

Walker, R. (2004). Ka Whawhai Tonu Matou: Struggle Without End (revised ed.). Auckland: Penguin.

Ward, A. (1991). Interpreting the Treaty of Waitangi. The Maori resurgence and race relations in New Zealand. The Contemporary Pacific, 3(1), 85-113. 